\title{
Criminal Policy and The Role of The Government in The Control of Commercial Sex Workers in The District of Kuningan
}

\author{
Nanang Suhendar ${ }^{1}$ and Sri Kusriyah ${ }^{2}$
}

\begin{abstract}
In Containment measures undertaken by the Local Government District of Kuningan to the presence of prostitutes is to use a penal policy that is with the issuance of Regulation No. 3 of 2015 on Public Order and Peace Society. These regulations are still too general and not specifically discuss countermeasures against prostitutes. Based on Regulation No. 3 of 2015, there are at least three agencies that have the authority and responsibility directly to the PSK reduction in Kuningan regency. All the three agencies including the Department of Social and Labor of Kuningan district. Kuningan regency and municipal Police District of Kuningan. The research is qualitative research in the form of descriptive analysis using sociological juridical approach. Prevention efforts refresif PSK only be done by way of a raid conducted by the municipal police and the Police of Kuningan. PSK is captured in the raid, was ordered to make a statement and then forced the release back. This is done because the Department of Social Welfare and Labor as the institution in charge to distribute PSK to rehab in palimanan not receive distribution PSK. This happens because of a rehabilitation center in palimanan quota is full and PSK for Kuningan district just 10 people. Related Bylaw PSK reduction should be set so that preventive efforts can be carried out preventive and repressive. Keywords: Criminal Policy; Commercial Sex Workers; Local Government.
\end{abstract}

\section{Introduction}

District of Kuningan is one area that has a number of problems related to prostitution. According to the Chairman of the National AIDS Commission Kuningan, Asep Susan Sonjaya as reported by tempo, in 2013 the number of prostitutes in the district of Kuningan about 700 people. Many of the prostitutes who conduct transactions in the cafes and in the tourist areas and Sangkanhurip Linggarjati. The liaison, usually a motorcycle taxi driver who often offer the hotel guests to enjoy the cool air at the foot of Mount Ceremai.

According to Adang Sumbada, one of the NGOs that investigate the existence of prostitution in Kuningan, 90\% PSK is a call while the rest is hung in place. For his own native region only $40 \%$ of prostitutes are from Kuningan while the rest comes from outside Kuningan. Kuningan boarding house and cafe in a trend where prostitution being safe from raids. ${ }^{3}$ With the proliferation of boarding and nightclubs in Kuningan make sex workers more and more calls. Kostan used as venues for prostitution

\footnotetext{
${ }^{1}$ Student of Master of Law, Universitas Islam Sultan Agung Semarang and Police email: nanangsuhendarpolri2018@gmail.com

${ }^{2}$ Lecturer of Faculty of Law UNISSULA Semarang

${ }^{3}$ http://www.radarcirebon.com/kosan-tempat-prostitusi-terselubung.html accessed on May 202018 at 9:10
} 
scattered at various angles in the town of Kuningan. For those who already know the network must have memorized where the location of the call PSK boarding. PSK professions ranging from students, an employee, the guide track to housewives. The price was ranging from hundreds of thousands to millions. The clientele ranging from the mundane to the upper class people. The reason they become prostitutes in addition to economic factors also already because it has lost virginity undertaken by partner during courtship.

The development of the practice of prostitution in addition to conflicting with social norms and religion, may also lead to an increasing trend of sexually transmitted diseases in the community or at the call of sexually transmitted infections (STIs), and undermine people's mentality, especially among young people who are vulnerable to negative access of cultures prostitution. Based on data from Kuningan district health offices, the number of people living with HIV / AIDS were 43 persons infected with HIV / AIDS, three of them had died. The number was among as many as 11 Mother Households with HIV / Aids, 1 PSK, 12 employees, 3 driver, 3 employees of the salon, 2 saleswoman, 1 tailor, 1 laborer, two inmates, two elementary school students, and four children were not attending school. ${ }^{4}$ One of the HIV / AIDS transmission is through sexual contact, especially sexual promiscuity made in the practice of prostitution.

Realizing the danger of complexity due to the presence PSK, Kuningan District Government made a policy as an attempt to cope with the presence of PSK. Policies are made is still a Regional Regulation No. 3 of 2015 on the Implementation of Public Order and Peace Society. Prohibition become prostitutes contained in Chapter VIII of article 31 of Regulation No. 3 in 2015, while for sanctions violations subject to administrative sanctions and criminal sanctions described in Chapter XI and Chapter XII. Policies in tackling the complexity of the problems PSK focused on efforts to follow up and handling the problems prostitution. ${ }^{5}$ Monitoring and enforcement functions with respect to the PSK implemented by the Civil Service Police Unit in coordination with the police and other relevant agencies. The initial phase of treatment PSK done by Satpol PP and the Police of Kuningan is to conduct raids.

The absence of regulation District of Kuningan specifically addressing issues of PSK make efforts undertaken by the Police District of Kuningan merely record the names of prostitutes who netted in the raid later released, were sometimes PSK netted taken to a rehabilitation center in palimanan however this is very rarely do. This is due to the capacity of the rehabilitation in palimanan is not sufficient anymore because palimanan is the only rehabilitation center in Region III Cirebon. The efforts made over the course would not make PSK deterrent so it is not surprising that the number of sex workers continues to grow from year to year.

Based on the above, the authors are interested in doing research with the title "Criminal Policy And The Role Of The Government In The Control Of Commercial Sex Workers In The District Of Kuningan".

\footnotetext{
${ }^{4}$ http://nasional.tempo.co/read/news/2014/01/10/058543603/ada-12-ribu-pelanggan-psk-di brass accessed on May 202018 at 9:15

${ }^{5}$ Departemen Sosial RI 1984 Pola Dasar Pembangunan Bidang Kesejahteraan Sosial p. 23
} 


\section{Research Methods}

This type of research used in this study is a qualitative research. Qualitative research is a study aimed at describing and analyzing phenomena, events, social activities, attitudes, beliefs and thoughts of people individually or in groups.

\section{Results and Discussion}

PSK in Kuningan district continues to increase along with the proliferation of tourist resorts in the area. Tourism has become a magnet meetings between prostitutes and their clients, grow and develop the surrounding cafes and budget hotels at affordable prices. Based on data from the National AIDS Commission, in 2015 the number of prostitutes in the district of Kuningan are based on a population at high risk for AIDS numbered 704, spread across Sangkanhurip, Pasawahan and Cibereum.

Economic factors are the main cause of the number of prostitutes in the district of Kuningan. Divorce causes women to be self-sufficient in meeting the needs of life and family. When women do not have the experience and ability to work it into prostitution is a choice that had to be lived. Factors to friends who had first become prostitutes also be a strong incentive to enter into the world of prostitution. The divorce rate in the Kuningan district has increased every year. Based on BPS data in 2014 the number of divorces totaled 1163 cases and an increase of 87 cases in a year. This figure also potentially lead to more women become prostitutes as a result of divorce.

Efforts made by Local Government District of Kuningan in tackling PSK limited to repressive efforts. This work is done by the municipal police and the Police District of Kuningan with raids are conducted. PSK caught raids, ordered to make a statement, briefed then released again.

Rehabilitation efforts conducted by the Department of Social and Labor District of Kuningan by sending prostitutes to Rehabilitation in palimanan to be briefed and the provision of a number of skills. But this time, the rehabilitation center will no longer receive PSK because the amount is full, the quota assigned to the District of Kuningan only 10 people, while the number of prostitutes in Kuningan regency over the quota. Therefore, prostitutes are exposed to raids only briefed and released. This obviously does not make PSK deterrent and has the potential to do business of prostitution back. Combating crime is essentially the integral protection of the public. Therefore it can be said that the purpose ahir or primary purpose of criminal politics is the protection of society to achieve social welfare. Enforcement of criminal law is part of a crime prevention policy (criminal politics), with the aim ahir is the protection of society to prosper. Thus the criminal law enforcement in the form of refinement pereturan legislation with the adoption and implementation of criminal law and improve community participation to participate in tackling crime.

Steps to be taken in Poverty PSK in Kuningan district by carrying out penal policy among others:

- Article 296 The Book of the Criminal Justice Act 
In the Book of the Criminal Justice Act ("Penal Code") itself, prostitution is regulated in Article 296 of the Criminal Code, which reads: "Whoever intentionally causing or facilitating obscene acts by other people with other people, and make it as search or custom shall be punishable by imprisonment of one year and four months or a maximum fine of fifteen thousand rupiah."

This provision not only prohibits making easy acts violate general decency in places of prostitution, but also act makes it doing acts that violate common decency that is not done for a living or habit.

Included in the definition of "simplify" is the act also rents out rooms to give the opportunity to others to commit acts of violating decency. To "facilitate" is not necessary an action to do something or not do something active than an obligation prescribed by law.

Can be said to have done a "habit", that action must be taken repeatedly and between acts with each other, there should be a relationship, so it is not enough if the action in the indictment only mentioned the word "often".

Laws governing prostitution or prostitution, especially in Indonesia is obviously there, but here it can be seen sense pimps legally is a man or a woman who acts provide facilities and make itself an intermediary obscene as a habit or livelihood, also profited from prostitution, Actions undertaken by the pimps are actions that violate the regulations stipulated in the Criminal Justice Act.

The definition of a lewd act itself, referring to R. Susilo explanations concerning Article $\mathbf{2 8 9}$ of the Criminal Code, namely all acts that violate morality (propriety) or abominable deeds, all in the neighborhood of lust sex, such as kissing, groping member pubic, groped the breasts, and so on. Copulation included also in the sense of obscene acts.

Further said that to apply Article 296 of the Criminal Code, for example people who provide home or rooms for women and men for prostitution (sexual intercourse or sex lust release). Usually for it provided the bed.

- Kuningan District Regulation No. 3 of 2015 on Public Order

Regional regulations are regulations established by the Board of Representatives (DPRD) by mutual consent, namely Regional Head Regent of Kuningan. PSK alleviation efforts, the Government of the District of Kuningan guided by the Regional Regulation No. 3 of 2015 concerning public order.

Based on article 31 paragraph 1 no one is allowed to behave and / or do immoral on the road, the green belt and the park or other public places. Article 31, paragraph 2, states that every person is prohibited:

- become commercial sex workers;

- enjoin, facilitate, entice, coerce others to become commercial sex workers;

- use the services of commercial sex workers.

- are in place or boarding room or rented, hotels, guesthouses and the like with another couple types (not unrelated) and without having an official identity.

Article 38 implicitly asserts that every person who become prostitutes, pimps or prostitutes service users will get penalized in the form of verbal warning, written warning and a fine of administration. As for the place that made prostitution will be 
given administrative sanctions such as verbal warning, written warning, demolition, temporary cessation of activities, administrative fines, revocation of licenses, and license suspension or sealing.

According to Article $40 \mathrm{In}$ addition to administrative sanctions, for violations of the Regulation is liable to imprisonment for a maximum of 6 (six) months or a maximum fine of Rp. 50,000,000, - (fifty million rupiah).

Crime prevention efforts through non penal facility would be to have preventive properties, so that the main target is the handling of the causative factors of the crime. Such factors are addressed on the condition of the social conditions that directly or indirectly lead to a crime or a criminal act. Non penal efforts can include a very broad field once in all sectors of social policy such as sponsorship and social education in order to develop the social responsibility of citizens, the cultivation of community mental health through moral education, religion and so on. The primary objective of non penal efforts is to improve certain social conditions, but indirectly have a preventive effect on crime.

In counterness of PSK in Kuningan district's, Local Government repressive actions alone that with the enactment of legislation on public order and for the efforts of Non Penal Local Government and Police is the only new activities that are social calls only. Effort non penal effort for the Prevention of prostitutes in Kuningan District include:

- Establish an agency or team coordination of all efforts to address prostitution conducted by several agencies.

Kuningan District Government has a team of AIDS, Department of Social and Labor in Kuningan, municipal police and the Police. However, during this coordination is not carried out by the relevant agencies. To that end, the Local Government District of Kuningan able to coordinate among the four agencies. In addition Kuningan District Government may also establish response team PSK in villages in the district of Kuningan.

- Creating an assortment of busyness and recreational opportunities for children puberty to channel the excess energy. Kuningan has many parks and places for recreation. Utilization of these sights must be monitored so as not to be used as a place for activities that violate the norms of decency. In addition, managers of parks and sites should also be empowered parks and attractions for positive activities.

- Activities rehabilitation and resocialization through moral and religious education, job training and vocational education in order for them to be creative and productive. This is done in the center rehabilitsi in palimanan, Kuningan regency not yet have a rehabilitation center for prostitutes.

Obstacles faced Kuningan District Government in the fight against prostitutes is because not been determined by local laws that specifically make the handling and control of prostitutes. If a law on prevention PSK has determined specifically the District of Kuningan local government can undertake a number of them; prefentiv efforts can be done by planting moral values and ethics in education and in the villages, the introduction of sex education, especially for teenagers as well as the dangers of prostitution and sex before marriage. While efforts refresif can be done by 
increasing the integrated raid carried out by the municipal police and the Police District of Kuningan, manufacture shelters and rehab to accommodate,

\section{Closing}

\subsection{Conclusion}

- Criminal policy which is taken in counterness of prostitutes in the district of Kuningan taken in two ways Penal policy applying normative rules that exist through the application of Article 296 Book of Law Criminal law governing the practice of prostitution in which pimps or procurers can be prosecuted under this section, only Any application of this article is limited to snare pimp just being right for its actors or objects that prostitutes and people who use the services of prostitutes is not regulated by the Act therefore the local government issued a local regulation is regulation District of Kuningan No. 3 of 2015 on public order which ArticleArticle 31, paragraph 1 states every person prohibited act and / or do immoral on the road, the green belt and the park or other public places. Article 31, paragraph 2, states that no one is allowed into the commercial sex workers; enjoin, facilitate, entice, compel others to become commercial sex workers; use the services of commercial sex workers; are in place or boarding room or rented, hotels, guesthouses and the like with another couple types (not mahram), and without having an official identity.

Non Penal Policy efforts can include a very broad field once in all sectors of social policy such as Establish an agency or team coordination of all efforts to address prostitution conducted by several agencies, Activities rehabilitation and resocialization through moral and religious education, job training and vocational education in order for them to be creative and productive. This is done in the center rehabilitsi in palimanan.

- Efforts made Kuningan District Government in tackling the PSK is still limited to repressive efforts in accordance with the Kuningan Regency Regulation No. 3 of 2015 was to hold a raid conducted by the municipal police and the Police District District of Kuningan. While the repressive efforts undertaken by the Department of Social and Labor District of Kuningan such as data collection and delivery PSK to a rehabilitation center in palimanan with the quota only 10 people. Preventive measures have not been carried out by local governments District of Kuningan.

The obstacles faced by related reduction in Kuningan regency PSK is a strong lack of coordination made between the relevant agencies. Differences in the distribution of data on the number of prostitutes in the district of Kuningan issued by the Department of Labor and the National AIDS Commission showed a lack of coordination regarding the distribution of the number of prostitutes. The absence of joint raids programs between the Police and municipal police also showed no establishment of cooperation between the two institutions. PSK prevention efforts are implemented optimally less repressive as PSK affected by raids only be ordered to make a statement later released. Although there is no hall penampunga while for prostitutes but the police and municipal police could seek guidance and counseling 
about the negative effects of being a prostitute. Preventive has not been taken by the District Government of Kuningan because there is no clear and binding rules related to the handling and control of prostitutes. Clear and binding rules in the form of Regional Regulation Countermeasures PSK in Kuningan District. Meanwhile, to establish a local ordinance required that can not budget a little.

- Solution by the local government Kuningan district in the prevention PSK is with the efforts of a preventive nature embodied in activities to prevent prostitution among other enhancements Act on the prohibition or regulation implementation of PSK, intensification giving religious education and spirituality, Expanding employment for women, Provision of sex education and understanding the value of marriage in family life, and promote the welfare in general.

Efforts that are repressive namely Through localization, Activities of rehabilitation and social reintegration through moral and religious education, job training and vocational education, provide new employment opportunities for those willing to leave the profession PSK, find a spouse who is a permanent or a husband for prostitutes to bring them to the streets correct, and Guidance for PSK according to their talents and interests of each.

\subsection{Suggestions}

- Distribution of the number of sex workers in the area centered Linggarjati and Sangkanhurip, for it should municipal police and Police District of Kuningan increase to two raids in the area.

- Kuningan regency administration is still limited to the repressive efforts in the prevention of prostitution, whereas the distribution of the number of prostitutes in the district of Kuningan increasing. It required preventive measures which are presumably intended number of prostitutes is not increasing. To perform a number of these efforts, we need a strong legal and binding. For the Local Government should submit a draft regulation related to the prevention PSK Kuningan district legislature. In addition to making efforts prefentiv, with the Regional Regulation Countermeasures PSK can also be built a rehabilitation center for prostitutes.

- Concepted data collection should be carried out by the relevant agencies especially the Department of Social Welfare and Labor has the task directly in the response to the PSK. Begitujuga with municipal police and the police, should cooperate in conducting raids at a number of hotels, cafes and nightclubs in Kuningan temapt as well as an affidavit made by PSK should be made to the database for comparison with the Department of Social and Labor District of Kuningan.

- Coordination should be done in the form of evaluations and "sit down together" to discuss problems and find a way out prostitutes in the process of handling. Do not wait until the new law created then take action.

\section{Bibliography}

[1] Departemen Sosial RI 1984 Pola Dasar Pembangunan Bidang Kesejahteraan Sosial

[2] Bab II Tinjauan Literatur Teori Kebijakan Publik Jakarta: Universitas Indonesia 
[3] Budi Winarno 2002 Teori dan Proses Kebijakan Publik Yogyakarta: Media Pressindo

[4] R Christyna Pardede 2008 Upaya Kepolisian dan peran serta masyarakat dalam Menanggulangi Kejahatan Prostitusi Medan: Universitas Sumatera Utara

[5] Simandjuntak 1981 Beberapa Aspek Patologi Sosial Bandung: Alumni

[6] Soedjono D 1982 Patologi Sosial Bandung: Alumni

[7] S, Alam, A 1984 Pelacuran dan Pemerasan Bandung: Alumni.

[8] Kuningan Regency Regulation No 3 of 2015

[9] http://www.radarcirebon.com/kosan-tempat-prostitusi-terselubung.html accessed on January 11, 2016 at 9:10

[10] http://nasional.tempo.co/read/news/2014/01/10/058543603/ada-12-ribupelanggan-psk-di Kuningan accessed on January 11, 2016 at 9:15 